\title{
Anaplastic Large Cell Lymphoma, Giant Cell Rich Subtype
}

National Cancer Institute

\section{Source}

National Cancer Institute. Anaplastic Large Cell Lymphoma, Giant Cell Rich Subtype. NCI

Thesaurus. Code C39674.

An anaplastic large cell lymphoma characterized by the presence of numerous giant cells. 